\title{
Reinstating Shakespeare's Instrumental Music
}

The children's theatre companies, that by 1600 according to Shakespeare's Hamlet were commercial rivals of the adults, were formed initially of choirboys at St Paul's and the Chapel Royal, and not surprisingly, therefore, pioneering studies from the early twentieth century like those by Harold Newcomb Hillebrand and Charles William Wallace emphasized their distinctiveness through the quality of their music. ${ }^{1}$ According to William Lawrence, the children's companies compensated for their inability to represent 'human passion', and distinguished themselves from the adult theatre, by elaborate musical interludes and a concert before the play began. ${ }^{2}$ Only with the first edition, in 1970, of Andrew Gurr's scholarly and enormously influential The Shakespearean Stage 1574-1642, however, does this distinction come specifically at the expense of downgrading the level of music in Shakespeare's theatre, denying the adult players consort music until 1608 and restricting musical instruments at outdoor theatres to '[d]rums, trumpet, fiddles and flutes' as the 'standard accessories to performances'. ${ }^{3}$ Gurr's fourth and latest edition distinguishes 'Blackfriars with its famous consort of musicians' from '[m] usic in the amphitheatres' which 'was more limited, commonly introduced as a song with or without accompaniment', or characterized by a 'flourish of trumpets'. ${ }^{4}$ According to this theory, instrumental music, ie consort music with strings and woodwinds, if it existed at all in the pre-1609 theatre of Shakespeare, was very rare and generally performed by professional musicians brought in for the purpose. Not until after the King's Men regained the use of Blackfriars, we are told, together with its supposedly permanent consort of musicians, did they introduce instrumental music into the Globe, with the installation of a music room over the stage.

This paper will question this theory which through repetition has now taken on the status, particularly in interdisciplinary studies, of historical fact, ${ }^{5}$ suggesting that the difference between the two theatres was not as 
distinct as it suggests, and presenting evidence that Shakespeare exploited the full range of musical resources available to him throughout his career.

One of the least satisfactory aspects of this theory is the effect it has had upon the musical practitioners at the new Globe who have been conditioned to doubt whether Shakespeare used consort music, and therefore the validity of their own attempts to recreate it. In a publication chronicling their first ten years, Claire van Kampen concludes, 'we have established that the first Globe, at least until around 1610 or so, was a simpler affair than ours, musically speaking, due to the lack of facilities to create off-stage music cues effectively'. Keith McGowan explains, 'I characterise what we do in "original practices" productions at the modern Globe as more like the sort of rich musical experience you might have got at an indoor theatre but played in an outdoor auditorium'. Put at its crudest, in the words of James Wallace, going indoors involved 'woodwind and string replacing brass and drum'. ${ }^{6}$

Since Gurr first propounded his theory, however, the scholarly landscape has changed and Linda Austern has convincingly demonstrated that the two traditions were musically much less different than early critics had supposed. After an analysis of all extant plays written for London performance between ca 1575 and 1625, she concludes, 'A careful reading of this body of plays reveals more historical continuity and less of a manifest musical contrast between children's and adult's drama than previous emphasis had implied'. She finds similarities in almost every aspect of their music, especially in the use of popular tunes and lyrics, and in a variable level of musical content in both theatres, even in songs, which she finds at least partly dependent on genre as well as on the individual predilections of playwrights; William Shakespeare, she notes, 'clearly loved music and recognized its dramatic power.7 David Lindley is more guarded in accepting the possibility of instrumental music being performed by the adult players before 1608, and is doubtful that it extended to what he calls 'a Thomas Morley-style "mixed consort". 8

One of Gurr's leading arguments is acoustical. 'The difference in decibel levels required by the two types of playhouse', he says, 'demanded different kinds of instrument', and he is particularly insistent that the trumpet was too loud for indoor performance and was replaced there by the cornett. ${ }^{9}$ Undoubtedly there were differences in acoustics between the two types of theatre, but whether they constituted, as he has argued, an impediment to the use of consort instruments in the amphitheatres seems open to doubt. Bruce Smith has shown that, whilst they may have differed in the materials used for construction, the two types of theatre shared most of the same 
sorts of materials in their lining — mainly of wood, also favoured in the temporary constructions in the period of theatres inside other buildings. ${ }^{10}$ Thus indoor and outdoor theatres had similar acoustic surfaces. Alberti's commentary on Vitruvius recommends the use of a temporary 'Cieling to the Theatre, both to keep off the Weather, and to retain the Voice', and the canopy or 'shadow' built by the Elizabethans over amphitheatre stages very likely had a similar dual function. ${ }^{11}$ John Orrell suggests it acted as a 'sounding board'. ${ }^{12}$ According to Smith, the primary difference between the two types of wood-lined theatres lies in their shapes: that of the amphitheatres providing a 'broad', more focused result, as opposed to the indoor theatres' more diffuse 'round' sound. The key point here, however, is Smith's positive judgment about the suitability of the Globe for instrumental music: 'The South Bank amphitheatres were, in fact, instruments for producing, shaping, and propagating sound', and by modern acoustical standards proved 'just within the range of conditions' 'excellent for speech and music.'13 William Lyons, one of the modern Globe's musical directors, confirms this assessment: 'I have seen audiences focus their attention on the quieter instruments ... when you have had just a lute or a viol playing, audiences will pick up on that pretty quickly. I suppose it is part of retraining them to appreciate nonamplified sound'. ${ }^{14}$ Referring to the production of Howard Brenton's Anne Boleyn, he writes: 'The viols, whether used in pizzicato or arco were clearly audible throughout the play, and their dynamic adaptability was extremely useful. The same goes for the early violin'. ${ }^{15}$ Keith McGowan, another musical director, indicates that the Globe's acoustics will carry 'a very broad palette of musical timbres, from very gentle sounds (lute, viol, flute) to a big noise to accompany dancing (shawms, percussion). ${ }^{16}$

Austern insists trumpets were used in children's plays, and whilst some of her evidence is problematic (it is not clear, for instance, how much of the satire in The Knight of the Burning Pestle is concerned with supposed attempts to introduce alien amphitheatre practices into Paul's, whilst the use of trumpets in Epicoene is meant to be transgressive), several of her examples, as in The Revenge of Bussy D'Ambois and Cupid's Revenge, do seem to establish the existence of this practice. ${ }^{17}$ In some respects, however, the cornett/ trumpet dichotomy introduced by Gurr is less significant than it at first appears. Elizabeth and James both had trumpets in their indoor halls, even at masques, ${ }^{18}$ whilst unlike their modern equivalents, the Elizabethan timbres, of softer brass and harsher woodwind, much of it played out of doors, are relatively similar. It seems more likely that the later preference for the 
cornett/shawm was less to do with supposed acoustic differences than with their greater flexibility as instruments. ${ }^{19}$

The argument that two types of acoustics required two sets of instruments breaks down completely when brought into conjunction with Gurr's supposition that after 1608 the Blackfriars consort switched back and forth between the King's Men's two theatres. The acoustics could not have been unsuitable for consort instruments in pre-1608 Globe productions, but perfectly satisfactory for the very same instruments after 1608 .

Those who seek to widen the gap between musical provision in indoor and outdoor theatres seize upon a remark in the Induction to the King's Men version of The Malcontent. William Sly, pretending to be a gallant from Blackfriars, quizzes Richard Burbage, appearing in his own person, as to the play's origins, why they have stolen it, and why there are additions to Marston's original, some of which, says Burbage, are to make up for 'the not-received custom of music in our theatre'. According to Gurr, 'This presumably means they lacked ... strings and woodwinds', whilst to Lindley, it is '[u]nambiguous ... testimony to the difference of musical practice'. ${ }^{20}$ In fact, the King's Men lacked neither suitable instruments nor experience of their use, as evinced in the recent success of Twelfth Night, which clearly involved an instrumental consort. Instead, the 'custom' referred to was mostly likely that of interrupting the play for inter-act music, necessary in indoor theatres to trim the candles but a mere impediment to the flow of the drama out of doors. According to Bernard Harris, Ben Jonson had recently introduced music between the acts into Sejanus, first performed at court in $1603,{ }^{21}$ but then when it was performed in early 1604 at the Globe, just before their production of The Malcontent, a hostile public greeted this unfamiliar convention with 'beastly rage' and 'in passion'. ${ }^{22}$ The delay between acts could very well have been the last straw in a play which makes so few concessions to a popular audience, as Dr Johnson puts it, quoting Young: 'Jonson ... was very learned, as Sampson was very strong, to his own hurt. Blind to the nature of tragedy, he pulled down all antiquity on his head, and buried himself under it. ${ }^{23}$ In respect of 'the not-received custom of music in our theatre', therefore, this particular, unfortunate context, rather than the King's Men's musical incompetence, reasonably deserves blame for the failure of the attempted innovation of inter-act music, for as Austern points out, comparison of the two editions shows that every single musical cue from within the original text, including all the inter-act music integral to much of the action, has been included in the adults' edition. ${ }^{24}$ 
Perhaps regrettably, attitudes to John Marston remain coloured by Jonson's satirical and distinctly unappreciative account of his one-time collaborator as 'Crispinus' in The Poetaster with his red hair and little legs, which tends to obscure Marston's unique and highly talented contribution to Elizabethan and Jacobean drama. To a very large extent he may be credited with creating a new children's theatre, first with the choir school at St Paul's from ca 1599, and then transferring to the newly re-formed Children of the Queen's Revels in 1604. Certainly other dramatists were associated with the project - Jonson himself, Chapman and Middleton, Beaumont and Fletcher, and lesser lights like Daniel and Barry - but it is Marston who stamps his identity upon post-1599 children's theatre with his early work performed by young children, as Lyly had on its previous manifestation in the 1580s. The period ca 1599-1603 was a brief transitional phase, when the connection with the choir school and royal musicians was still active, in which chorister theatre with its under-developed plots, formulaic characterizations, and preponderance of music, especially vocal interludes, was transformed into a witty and satirical commentary on adult theatre.

Antonio's Revenge (1599-1600), for instance, exploits at every turn the musical potential of the young performers for pathos, humour, contrast, surprise, as well as the more conventional functions of royal entries, vocal accompaniment, dumb shows, masquing, and dances. The inter-act music of The Malcontent demonstrates a more theatrical sensibility than any dramatist short of Shakespeare:

\section{SCENA QVINTA. A song.}

Whilst the Song is singing, enter Mendoza with his sworde drawne, standing readie to murder Ferneze as he flies from the Duches chamber.

ALL Strike, strike!

AUR Saue my Ferneze! ö saue my Ferneze!

\section{Enter FERNEZE in his shirt, and is received on MENDOZA'S sword.}

ALL Follow, persue!

AUR O saue my Ferneze!

MEnd Pierce, pierce, thou shallow foole drop there. (D2v) $)^{25}$ 
It would be a mistake, however, to take Marston's work as the model for generalizations about children's theatre extending over a much longer period than he was active, and even within his short career his work altered to take account of rapidly growing young performers, ever gaining in confidence and experience. Without his peculiar perspective, especially in creating a unique form of musical theatre, the ageing 'children' soon reverted to a very similar sort of theatre to that of the adults.

The peak of Marston's achievement is Sophonisba (1605-6), his last completed play. It requires cornetts, organ, recorders, viols, bass lute, and voices, and is exceptional both in the musical resources it requires and the highly dramatic uses to which they are put, including the elaborate ceremonial of consummation in which 'MASSINISSA draws a white ribbon forth of the bed as from the waist of SOPHO[NISBA]. ${ }^{26}$ In another example, Syphax drags Sophonisba on to inter-act music: 'Organ mixed with recorders for this act. SYPHAX, his dagger twined about her hair, drags in SOPHONISBA in her nightgown-petticoat'(sd 2.3-3.1) The play has a solemn sacrifice to music. Infernal music introduces the witch Erictho. A treble viol and a bass lute play softly as she approaches the bed disguised as Sophonisba. During the inter-act these instruments continue as Syphax discovers his terrible mistake. Finally with mournful solemnity Sophonisba's dead body is presented to the Romans. Marston's fully realized script is a unique record of the most powerful dramatic and erotic use of music in the period, anticipating Wilde's Salomé in its transgressive, hypnotic power. It also requires considerable maturity from its principal actors, a fact that no study of this genre has yet recognized.

According to Michael Shapiro, 'The members of a children's troupe ranged in age from ten to fifteen', and he specifies the careers of Samuel Pavy and Thomas Ravenscroft. ${ }^{27}$ Jonson's 'Epitaph on SP, a Child of QE Chapel' indicates Samuel Pavy was thirteen when he died in 1603, hence at his impressment by Giles in 1600 he would have been ten. ${ }^{28}$ The date of Ravenscroft's birth, however, is uncertain. Shapiro says Ravenscroft served in the choir of Paul's from 1598 or 1599 to 1604 , or from the ages of ten or eleven to fifteen, but the only contemporary reference to his age would make him just six in 1598, and dating his birth as 1590 is mere speculation. ${ }^{29}$

In stressing their juniority, Shapiro continues a tradition from Hillebrand, who professed himself captivated by their 'charm of piquant strangeness' and their 'precocious skill', concluding, 'I cannot help feeling that the fundamental attraction of the boy actors ... was the whimsical charm of masquerade', ${ }^{30}$ a theme repeated in Austern: 'The very name of the companies, with 
their emphasis on "children," suggested precocious talent, and, until the final years, conjured up images of exquisite musical ability and an ecclesiastical discipline that was amusingly incongruous with the bold plays and bawdiness for which they were famous. The actors were young, and they were selected by virtue of their beauty, grace, and, in most cases, their musical talent'. ${ }^{3}$ She excepts 'the final years' from this generalization about the children's theatre when she says, 'some of its star performers went on to win fame as adult actors in popular companies'. Missing here, however, is any acknowledgment of the earlier consequences of the ageing process, of the intervening period before they left, when the children were no longer quite so young, or quite so tuneful, and the talents they offered of a different quality from precocity and charm. Even though she assembles much of the material needed to challenge the received orthodoxy, on matters of theatre history rather than musicology, she fails to do so.

In fact, Pavey seems to have been the exception in terms of his age of recruitment, since of the eight boys impressed under Giles's warrant in 1600, Nathan Field's birth in 1587 would make him thirteen when he was taken, as was Thomas Clifton too when he was pressed (and eventually released). Fourteen was widely regarded as the age of male puberty, when voices would break and render the performer unsuitable for singing; ${ }^{32}$ so whether Field, for instance, was ever a singer is doubtful. Clifton's father Henry submitted in 1601, a year after the boy's impressment, that 'These were all children who were "noe way able or fit for singing, nor by anie the sayd confederates endeavoured to be taught to singe"'. 33 Field went on performing with the chapel children in their various formations until 1613, when he would have been twenty-six. Shapiro would have him as an exception, ${ }^{34}$ but the evidence would suggest otherwise, for two other children from the 1601 cast lists, John Underwood and William Ostler, appear to have transferred to the King's Men when they took possession of Blackfriars in 1608. ${ }^{35}$ We do not know their dates of birth, but they must have been at least eighteen when they did so, whilst other evidence suggests many of those who remained were of a similar age: in 1610 Robert Keysar complained that he had had to disperse 'a companye of the moste exparte and skilful actors within the realme of England to the number of eighteane or twentye persons all or moste of them trayened vp in that service, in the raigne of Queene Elizabeth for ten years together and afterwards preferred unto her Majesties service (ie Queen Anne) to be the Children of her Revells.' ${ }^{36}$ From this evidence it looks very much as though most of the original tranche of performers, along with other 
impressments at a similar period, remained together throughout the decade. When Sophonisba was published in 1606, and Field would have been nineteen, Marston refers to the entire company as 'youths', ${ }^{37}$ and in the same year the term was also used of their rivals, 'the Youthes of Paules, commonly cald the Children of Paules.' ${ }^{38}$ Indeed, ageing performers seem to have been characteristic of the former period too. As early as 1582, Sebastian Westcott's will revealed the existence of seven former members of the St Paul's choir still living in his house and presumably acting in his productions, ranging in age from sixteen to thirty years. 39

All of this evidence ought to have significant consequences in revising the orthodox view of what went on under the nomenclature of 'children's theatre' during the years 1604-10. It will no longer serve, for instance, to generalize about the relative effectiveness of female as against male roles during this period, as Shapiro does when he asserts 'the actors could usually portray female characters more convincingly than they could adult male characters, ${ }^{40}$ a view which Austern takes up both in her book and later in her contribution to Leslie Dunn's Embodied Voices, claiming that 'the youngest' actors 'whose natural tendencies were believed to be effeminate probably played extremely convincing women' when they 'put on the attyre, the gesture, the passions of a woman'. ${ }^{41}$ By the middle of this decade many of the actors in the children's companies would have been as old as some of those in the so-called adult theatres and just as capable of playing roles of either sex. Richard Burbage was only sixteen and presumably part of the company when he defended his father's takings with a broom-handle, Edward Alleyn and Ezekiel Fenn were both seventeen when they became sharers, and Shakespeare, of course, was a husband and father at eighteen. Fenn's inclusion here (though from later in the period) as a skilled player of female roles until he was nineteen, senior enough to be called before the privy council in 1637 as one of four leading players to represent the quality, ${ }^{42}$ is a reminder of the anachronism stalking conventional studies of Elizabethan theatre, that female roles were always played by the youngest, prettiest, and most dependent members of the companies, an assumption based on a concept of realism in casting which was quite foreign to the Elizabethans. Readers still in doubt should turn to the excellent study by Leslie Soule of 'Cocky Ros' as the performer of Ganymede in As You Like It, a sinewy, resilient, mocking male persona, descendant of the Aristophanic eiron and the medieval vice, shape-stealer and plot-motivator. ${ }^{43}$ Substantial evidence shows that leading female roles 
by the 1620 s were being played on average at the age of sixteen to seventeen and sometimes at twenty or even older. ${ }^{44}$

As the leading children's players entered early manhood in the period between 1603 and 1609, the fortunes of their companies saw rapid changes. Chambers thinks the scandal associated with Eastward Ho! in 1605 only broke on its publication in the autumn which caused Queen Anne in 1606 to withdraw her patronage from the Blackfriars company. ${ }^{45}$ This loss of patronage obliged them to drop her name from their title, and he thinks it probable that they then became subject to the master of the revels, like the adult players. In the same year, James issued a new commission to Giles specifically insisting that those impressed should not be used for acting. Although Marston had fled to escape the imprisonment suffered by Jonson and Chapman for their part in Eastward Ho!, in 1608 he was committed to Newgate probably for a play satirizing James's project to exploit Scottish silver. It seems to have broken him. He sold his share in the Blackfriars operation to Keysar and disappeared, leaving the Insatiate Countess unfinished. He surfaces as a parish priest in 1616 and remained one until shortly before his death in 1634 .

The theatre he created went on, but in name only. As the children grew and stayed on, milking the benefits of a royal juvenile company, their theatre rapidly became indistinguishable from that of the adults, as is evident in the work of Middleton, who wrote a series of lively satirical city comedies for Paul's, Your Five Gallants for Blackfriars in 1607, and A Chaste Maid in Cheapside and probably No Wit, No Help, Like a Woman's for Field and his friends in the Lady Elizabeth's at the Swan in 1613, and all substantially in the same style. Jonson's Bartholomew Fair at the Hope in 1614 similarly indicates the versatility, confidence, and relative lack of inhibition in female roles characteristic of this group, still quite young but many of them with fourteen years of theatrical experience.

After a sensitive and detailed study of Sophonisba, Austern concludes that its use of music is 'representative', ${ }^{46}$ yet there is no evidence that its wonders were ever repeated. Sophonisba is not an exemplum of the children's theatre but an exception, and the level of musical resources Marston calls for in this play does not appear to have been required in any other children's play of the period, as a survey of a selection of the children's repertory either side of the changeover shows, in which the texts are indistinguishable in their musical demands from adult texts: Beaumont's The Woman Hater (1605-7) has but a single song; Barry's Ram Alley (1607-8) has some musicians serenading a widow; Markham and Machin's The Dumb Knight (1607-8) has music but 
mainly for entries, battles, and dances; Beaumont's Knight of the Burning Pestle (1607) has songs and dances extending into the inter-act music its plot requires; Beaumont and Fletcher's Faithful Shepherdess (1608) has a number of songs; Chapman's The Conspiracy of Byron (1608) has a single 'Loud music' on the entry of its hero, and its sequel has a masque as, after the surrender of the lease to the King's Men, has Beaumont and Fletcher's The Coxcomb (1609); Jonson's Epicoene (1609-10) has a singing boy and some business with brass instruments; there is some music in Field's Woman is a Weathercock (1609-10) but only a single song in his Amends for Ladies (1610-11). What confirms this reversion to normal adult practice is the complete lack of the sort of detail, of instruments or the interaction of music and drama, that Marston so fulsomely presents. And if it was not required, would the private theatres have carried that level of musical resources by 1608 ? It rather looks as though for Sophonisba, Marston was able to call in the forces he needed from outside Blackfriars for this single production.

\section{Evidence of Consort Music at the Globe}

Christopher Marsh quotes Edward Fuller in 1656, 'England is celebrated abroad as the ringing island', and goes on to illustrate the 'sheer vibrancy of its musical culture' at this period. ${ }^{47}$ Overwhelming evidence indicates widespread instrumental facility in every stratum of Elizabethan society as well as the pleasure taken in it, and that this facility is reflected in the drama. At court, music accompanied almost every facet of the monarch's life from announcing royal entries, to accompanying meals and all manner of recreations. Elizabeth herself was an accomplished musician and her favourite occupation was dancing. Music was considered a necessary courtly accomplishment, recommended by Castiglione, and the period held various elaborate theories about its Platonic and therapeutic properties. ${ }^{48}$ Thomas Elyot talks of achieving human concord between the sexes through dancing. Skill in playing on the virginals or the lute was pressed on young women as a necessary accomplishment in the task of obtaining a husband. ${ }^{49}$ Edward Naylor surveys the ubiquity of music in genteel social life. ${ }^{50}$ Lower down the social scale, there were citterns in barber shops for customers to play, whilst ballads constituted a major cultural form of entertainment; even puritans, hostile to most forms of music, especially dancing, approved of singing psalms. Popular tunes crossed all social barriers and were taken up by composers to form the basis for the plethora of musical publications. Inevitably 
therefore, as the theatre attempted to recreate current mores, especially those of noble and courtly life, onstage, so it needed to employ the same sort of musical resources, and nowhere more so than in the plays of Shakespeare.

His plays show a pervasive interest in and knowledge of all aspects of music and its technical terms:

It is the lark that sings so out of tune,

Straining harsh discords and unpleasing sharps.

Some say the lark makes sweet division;

This doth not so, for she divideth us. (Romeo and Juliet 3.4.27-30.) ${ }^{51}$

How sour sweet music is

When time is broke, and no proportion kept!

So is it in the music of men's lives.

And here have I the daintiness of ear

To check time broke in a disordered string;

But for the concord of my state and time

Had not an ear to hear my true time broke. (Richard II 5.5.42-8.)

When Pericles divines the terrible secret of King Antiochus's daughter, automatically he reaches for a musical simile:

You are a fair viol, and your sense the strings;

Who, finger'd to make man his lawful music,

Would draw heaven down, and all the gods to hearken;

But being play'd upon before your time,

Hell only danceth at so harsh a chime.

(Pericles 1.1.81-5.)

Unlike the decorative use of music and singing in the children's theatre, Shakespeare's songs and instrumental music, as Lindley's excellent study shows, deepen our responses to the drama, as in the music of Ariel, Feste, and Lear's Fool; he creates layers of commentary and oppositional meaning in Twelfth Night, The Tempest, and with Falstaff and his cronies; he is able to use music to indicate a mind in stress (perhaps his original contribution); he uses it to evoke ritual and tradition in As You Like It and Winter's Tale; to accompany visions and to express the love and romance of Romeo and Juliet and Merchant of Venice. ${ }^{52}$

Thirty-eight instances in Shakespeare's plays appear to require a consort or group of instruments. These range across twenty-three out of his thirtyseven plays. Evidence indicates a similar breadth of use at the Rose, with 
sixteen examples of instrumental music between 1587 and 1598 in eight plays. They include serenades, characters charmed asleep, music as a restorative, entertaining nobles, entrances of beauty, passing time whilst something else happens, easing pains of death, visions, playing in and accompanying feasts, marking solemn moments, and, when more than one instrument appears to be involved, accompanying songs and dances. String and woodwind instruments tend at this period to be played in 'consort', ie in groups from the same family, so evidence of one, as in Hamlet, in many situations is likely to indicate more.

As far as possible the use of trumpets and drums (discussed below) is excluded from this survey, as are songs and dances accompanied by a single instrument. Nomenclature can pose problems: 'music', for instance, can refer to a single instrument, as in Julius Caesar:

BRUTUS Canst thou hold up thy heavy eyes awhile,

And touch thy instrument a strain or two?

Lucius Ay, my lord, an't please you.

BRUTUS

It does, my boy.

I trouble thee too much.

\section{Music and a song.}

$(4.3 .256-9,266)$

The instrument is presumably a lute.

Dances appear sometimes to be accompanied by a consort, but sometimes only by a drum as in $M u c h A d o$, or with a tabor and pipe, even apparently at court before Queen Elizabeth. ${ }^{53}$ Originally of course it was song that served to provide the rhythm for dancing, as in Antony and Cleopatra 2.7, where the Egyptian bacchanals are danced to a boy singer, though apparently supported by the 'battery' of 'loud music', and with the dancers joining in the refrain.

Even those supporters of the differential theory who do accept the existence of consort music in the pre-1608 amphitheatres still resist player-performance by suggesting that instead they imported musicians for any activities beyond the blowing of trumpets and banging of drums. ${ }^{54}$ The city waits, originally watchmen with ox-horns, came to be a band of trained musicians with an ever-expanding array of instruments, attendant at civic functions on the lord mayor and aldermen, to whom Morley dedicated his First Booke of Consort 
Lessons. At other times, the waits were available for hire and some evidence indicates they occasionally performed in theatres. ${ }^{55}$

Simple economics, however, suggest this hiring of waits was not a regular occurrence. Instead, plays were normally commissioned to exploit and display the existing skills of the players themselves, musical as well as histrionic, as well as their dancing, fencing, clowning, and tumbling, as is very evident in those Tudor interludes 'offered for acting'. Cambises, for instance, demonstrates the instrumental proficiency of the London players' itinerant predecessors: 'On Lute and Cittern there to play a heavenly harmony'; 56 whilst another play from the same period, Common Conditions, releases Players Three and Six for a musical entry. ${ }^{57}$ David Bevington emphasizes the versatility of the itinerant performer as far back as that repertory can be traced. ${ }^{58}$ The original patent given to the itinerant Leicester's Men in 1574 specifically, and separately, licenses them 'to use and occupie all such Instrumente as they have alreadie practised'. It goes on to list the different kinds of plays, and then adds 'to gether (sic) with their musicke'. ${ }^{59}$ Stephen Gosson provides testimony, if a hostile one, of their instrumental activities as soon as the players settle in London: 'There set they abroache straunge consortes of melody to tickle the eare; costly apparel, to flatter the sight; effeminate gestures, to ravish the sence; and wanton speache, to whet desire to inordinate lust'. ${ }^{60}$ 'Consortes of melody' no less!

The strongest argument against the employment of outside musicians for particular effects in the established theatres is the extremely varied nature of the play repertory, with different plays every day and even very popular plays perhaps repeated only weekly, ${ }^{61}$ as well as, one suspects, its semi-casual nature. Edmund Gayton gives a colourful account of the tyranny of holiday audiences, demanding snatches of three plays, insisting on a final jig, and pulling the theatre to bits if they were refused; written in 1654, long after the theatres had been closed, his description must have had some basis in reality. ${ }^{62}$

'Sneak's Noise' in 2 Henry $I V$ presents an interesting case. Were they represented by players, or did they come in their own persons? Evidently a popular group, they are mentioned in 1 Iron Age, when Thersites taunts Achilles with abandoning arms for a lute: 'Where's this great sword and buckler man of Greece? Wee shall haue him one of sneakes noise, and come peaking into the Tents of the Greeks, with, Will you have any musicke, Gentlemen?' (3.3.49-52). ${ }^{63}$ Contemporary charges against the lowly fiddler (a term used apparently irrespective of instrument) ${ }^{64}$ include playing badly, importuning 
for trade, and being too numerous: 'London is so full of unprofitable pipers and fiddlers, that a man can no sooner enter a tavern, than two or three cast of them hang at his heels, to give him a dance before he depart'. 65 The plays, too, reflect a similar attitude to the professional musician, engaged in an activity clearly regarded as the lowest of the low; hence musicians are paid very badly, and sometimes not at all, or the money thrown at their feet. 'Fiddlers wages' is a cant term for small change. ${ }^{66}$ Peter in Romeo and Juliet puns, "it is "music with her silver sound", because musicians have no gold for sounding' (4.5.140). The itinerant fiddler in Orlando Furioso thinks a groat (worth fourpence) a good fee; ${ }^{67}$ as a standard rate this seems to be confirmed in 1 Return from Parnassus. ${ }^{68}$ The relentless insult of fiddlers would seem to indicate that they were not brought in, especially to be abused, but that the players themselves assumed such roles, imitating them as a running joke, much as, say, foolish constables.

A 'consort', in Elizabethan terms, consisted of members of the same family of instruments, but both Thomas Morley's First Booke of Consort Lessons (1599) and Philip Rosseter's Lessons for Consort (1609) are scored for a 'broken' or 'mixed' consort; that is, transverse flute or recorder, treble viol, bass viol, cittern, and bandore, with the addition of a treble lute. According to Mary Chan, the bowed instruments and the flute would play the tune, and the plucked wire-stringed cittern and bandore would 'emphasise the rhythmic basis of the melody and the lute provides virtuoso variations of the melody in the repeated sections'. The broken consort, she says, 'is most suitable for performances of dance music and popular song. ${ }^{69}$ Much of Morley's material is arrangements of simple ballad and popular tunes. Their records show that both leading adult companies possessed these very instruments.

In 1605, in his will, Shakespeare's long-time colleague Augustine Phillips left a bass viol to Samuel Gifford and a cittern, bandore, and lute to James Sands, both fellows and former apprentices. Amongst his 1598 inventories, Henslowe lists for the Admiral's Men 'a trebel viall, a basse viall, a bandore, and a sytteren', all of which appear to have been purchased in the five months before the inventories were made (between October and February 1598: Henslowe's financial year ending on 1 April). ${ }^{70}$ Thus whilst Mary Chan and John Long both suggest that the common players performed their own music only until ca 1590 and then employed professionals, ${ }^{71}$ and David Lindley speculates that the increased use of music in As You Like It (1599) and Twelfth Night (1600) is in response to the success of the children, ${ }^{72}$ it looks instead very much as though Henslowe/Admirals are setting up their own broken 
consort just in time for the publication of Morley's book of consort lessons, and before the revival of the children's musical theatre, whilst Phillips's will indicates player-music still in action in $1605 .^{73}$

Under these circumstances - the ubiquity of instrumental music at court and in society; the implications this had for the players' performance; the way in which instrumental metaphors well up in Shakespeare's consciousness as he writes; the well-spaced but persistent requirements for consort music in the texts (consonant with men who have other things to do as well); and, surely clinching the matter, the presence in the tiring house of just those instruments that would be necessary - it seems wildly unlikely that Shakespeare and his fellows did not garnish his plays with their very best musical, and instrumental, endeavours.

Estimating the overall quantity of instrumental music is difficult, but since the adult companies had the instruments and players, the dramatic conventions for their use, and indications in the text that implied confidence in the effectiveness of 'soft' music outdoors, then there could have been much more than the texts record. According to Alan Dessen and Leslie Thomson, 'the basic signal, music, is found in the margins of stage plots and playhouse manuscripts. ${ }^{74}$ In other words, especially if the actors were themselves providing the music, it would often be one of the last matters to be decided and would therefore appear only in the licensed professionally-copied script, which was rarely available for printing, and other factors about the relationship of playscript to performance, too, might affect such matters. ${ }^{75}$ Nor can stage directions always be relied upon: in Winter's Tale (5.3.98) and Twelfth Night (1.1.1 and 2.4.1), for instance, no stage directions call for music, but the text itself does. Similarly, without Hamlet calling for recorders (at 3.2.345), we would not know of their existence. Lawrence points to a scene in the anonymous True Tragedie of Richard the Third (1590), where music accompanies the two little princes as they pray before their murder; it has no function other than to add to the pathos of the scene, but he offers it 'to show the amount of attention then being paid by the common players to incidental musical detail'. ${ }^{76}$

\section{The Implications of the Re-acquisition of the Blackfriars}

According to Gurr, '[t]he great change in the company's musical accompaniment came with the acquisition of the Blackfriars and its consort of professional musicians', ie in 1608, and later, '[t]hey were used at the Globe, since 
it seems to have been equipped with a musicians' gallery after 1608, but they must also have been frequently available for hire, particularly in the evenings' ${ }^{77}$ No direct evidence for this statement seems to exist.

Whether there was ever the sort of permanent consort that Lindley and Gurr envisage remains in doubt. ${ }^{78}$ Most scholars accept that the children performed only once a week, (though Mark Eccles suggests they might have performed more frequently). ${ }^{79}$ According to Gurr, the act break lasted only 'a minute or so'. ${ }^{80}$ Neither of these factors would suggest a permanent consort. The issue hinges for scholars on a single reference: in 1602 Blackfriars was honoured by a visit from the duke of Stettin-Pomerania, recorded by his secretary Frederick Gerschow in his diary, ${ }^{81}$ at which there was a preliminary concert, which may or may not have been a regular feature (for when the Spanish ambassador visited the Fortune, for instance, he too was given special treatment in the form of a banquet). ${ }^{82}$ It is difficult to conceive how such preliminary concerts unrelated to the drama — Marsh calls them 'curtainraising instrumental numbers' - would have fitted in with the apparently regular use of 'soundings', a series of three spaced-out trumpet calls, a convention presumably taken from the amphitheatres where they appear to have served to hasten spectators. ${ }^{83}$ 'Soundings' are included in the Inductions to Cynthia's Revels and The Poetaster to give the rather arch impression that the actors, by intervening before the third sounding, are in propriae personae and not part of the play itself; 84 and for 'soundings' to interrupt or even to follow a previous part of the entertainment would spoil this effect. Similarly, Austern points to music at the beginning of Satiromastix and The Malcontent which sets the mood of the opening scenes, but which is entirely different from the unrelated concert reported by Gerschow (and, it must be emphasized, by no-one else in this period). ${ }^{85}$ An alternative, as Shapiro suggests, is that 'the musicians at the private theatres after the late 1590s were choirboys, as they had been before 1591'. ${ }^{86}$ Playtexts from the period 1599-1604 offer plenty of evidence of the young performers' competence on such instruments as cornets, viols and lyra, harps, lutes, and theorbo. ${ }^{87}$ Significantly, however, all such evidence is drawn from their early years and none thereafter, when, as the review above has shown, the plays become less musical.

Nor does Gurr's theory, that it was possible to acquire a consort of musicians along with the theatre, and then hire them out, take cognizance of the casual, fluid nature of musical employment, then as now. Nobles, even kings, appointed musicians, as they did players, but expected them to find their own living when not actually in employment, as James Burbage's 1572 
letter to the earl of Leicester makes clear. ${ }^{88}$ So it is that all groups of musicians called on to entertain in Shakespeare's plays do so on a casual basis: 'Sneak's Noise' in 2 Henry IV, Cassio's attempt at a serenade, those Peter sends away in Romeo and Juliet, those brought by Thurio to woo Silvia in Two Gentlemen of Verona, and those used by Cloten in Cymbeline, together with the players and their recorders in Hamlet. Only Orsino's household musicians seem to hold the promise of regular employment, but the same play also demonstrates the casual nature of his relations with Feste. What emerges in Gurr's own meticulously assembled information on musicians is the fluidity of employment, of musicians on the move probably indifferent to employer or ethos and treated with little respect. Even Heminges has them arrested; John Adson and Richard Balls in the 1620s and 1630s, for instance, belonged to the Blackfriars consort and were also city waits, ${ }^{89}$ just as nowadays a musician may be in a prestigious Baroque consort on Monday, fill in with private students during the week, and end up on Saturday playing at a wedding. Scholars often cite Henry Herbert's list of twenty-two 'musicians and other necessary attendantes' of 1624 as evidence of the size of the King's Men company by then. Closer inspection reveals it is no such thing; the licence is to protect those named from summary arrest or being pressed for the army so that they 'ar att all tymes and howers to bee readie with their best endevors to do his Maiesties service (dureinge the tyme of the Revells). ${ }^{90}$ Dated 27 December, it refers only to the Christmas period of court performances, when the company's regular musical resources may well have been substantially augmented. In 1989, Michael Launchbury indicated the intention of having a permanent company at the new Globe, ${ }^{11}$ but the reality today is of occasional employment; in a list of twenty-five musicians employed in six productions, only ten of them took part in more than one production. ${ }^{92}$

The weakest part of the differential argument lies in delaying playing music on the gallery at the Globe until 1608 and accepting Richard Hosley's conclusions in this regard. 93 'When they took over the Blackfriars playhouse', says Gurr, ' $[\mathrm{t}]$ he housekeepers immediately altered the Globe stage-balcony to make a curtained music-room over its stage so the musicians could play there as well as at Blackfriars. ${ }^{44}$

In this area, the practical experience of the new Globe's musicians ought to have a direct impact on scholarship: firstly in William Lyons's observation that the gallery is the best place to project music, bouncing off the 'shadow' (as John Orrell had anticipated) — 'even quieter instruments such as lutes and viols work very well up in the gallery. There is something about the 
forward projection of the roof that directs the sound down; whereas on the stage, it can often get quite lost among the action, falling into the yard' 95 and secondly in Claire van Kampen's evident struggles to blend offstage music with onstage events, a situation which ought itself to question Hosley's conclusions that 'within' was the default position for musical performance. And if the effect of playing from the gallery is so markedly superior now, would not the original musicians also have found this and exploited it? It seems to me incredible that such a likelihood should continue to be swept aside in academic theory.

Hosley bases his conclusion that 'within' was the normal place for the music on sixteen references in stage directions in Globe plays:

Julius Caesar (1599), IV.ii (F, 1623): 'Low March within.'

A Warning for Fair Women (> 1599), sig.DI (Q, 1599): 'Here some strange solemne musike, like belles is heard within.'

Troilus and Cressida (1602), III, I (F, 1623): 'Musicke sounds within.'

All's Well That Ends Well (1602-3) IV, I (F, 1623 'Alarum within.'

All's Well That Ends Well (1602-3) IV, I (F, 1623 'A short Alarum within.'

Othello (1604?), II, i (Q, 1622): 'Trumpets within.'

King Lear (1605), I, iv (F 1623): 'Hornes within.'

King Lear (1605), II, i 'Tucket within.'

King Lear (1605), II, iv 'Tucket within.'

King Lear (1605), V,ii 'Alarum within.'

King Lear (1605), V,ii 'Alarum and Retreate within.'

King Lear (1605), V.iii 'Trumpet answers within.'

Macbeth (1606), I,ii 'Alarum within.'

Macbeth (1606), I,iii 'Drum within.'

Macbeth (1606), III,v 'Musicke and a Song ... Sing within Come away, come away, \&c.'

The Devil's Charter (1607), sig.M2 (Q, 1607): 'Sound a Horne within'. ${ }^{96}$

Thirteen of Hosley's examples, however, involve drums or unvalved brass instruments, and not musical instruments as they were then conceived. As Gurr himself points out, '[a]t this time trumpets and drums were not considered to be primarily musical instruments. Trumpets were not used in art music until the first performance of Monteverdi's Orpheo (1607) in Italy'. ${ }^{97}$ 
Dr Faustus scene 11 exactly catches the distinction: 'Then trumpets cease and Musicke sounds. ${ }^{98}$ Although Marsh thinks in terms of special performers of trumpets and drums, both Lindley and Smith observe that playing the sixteenth-century equivalent of a modern bugle is not a skill but a knack, ${ }^{99}$ and whilst it is conceivable, if unlikely, that special trumpeters could have been imported for plays dealing with battles or kings, the fact that trumpets were used on an everyday basis to announce the beginning of the plays and lead touring companies into towns argues that they were played by regular members of the company. Hence thirteen of Hosley's examples would routinely have been played from within the tiring house by the players themselves, thus reducing his examples of actual music being played 'within' to just three, and leaving his theory almost unsupported.

Far more frequently, stage directions use the single word 'Musicke', which would suggest 'Music within' is exceptional — a book-keeper's advance warning requiring the player-musicians stationed on the gallery to go down the back stairs for a specific cue to create what Celia Daileader calls the 'diegetic space', ie that 'referred to by characters', ${ }^{100}$ an adjacent imaginary location or event behind the apertures, a feast in another room, say. It does not occur frequently perhaps because, as Clair van Kampen indicates, gauging the appropriate level of sound so as not to interfere with the dialogue can be difficult. ${ }^{101}$

More often, however, music services action that takes place on the platform stage itself. Just as the stage façade is invoked as palace, great hall, banqueting room, so too in many instances the gallery becomes that of the minstrels; whenever a monarch or lord calls for music it is reasonable to assume he is designating the gallery and its musicians as being in his house or palace, as in Twelfth Night for example:

DUKE If music be the food of love, play on,

Give me excess of it ...

Not infrequently the gallery takes on a celestial function, as in 1 Henry $I V$ :

GLENDOWER And those musicians that shall play to you

Hang in the air a thousand leagues from hence,

And straight they shall be here

In many cases, however, a fictive pretext is dispensed with, as in this example from Much Ado: 
BENEDICK Come, come, we are friends. Let's have a dance ere we are married,

that we may lighten our own hearts and our wives' heels.

LEONATO We'll have dancing afterward.

BENEDICK First, of my word; therefore play, music. (5.4.117-21)

A messenger arrives with news of Don John's capture.

BENEDICK Think not on him till tomorrow. I'll devise thee brave

punishments for him. Strike up, pipers. Dance [Exeunt].

Their supposed location, whether at church or in Leonato's house, is not stated, the purpose of the assembly supposedly being the marriage of Claudio to an unknown woman. Musicians are not acknowledged as present, so Benedick could well be commanding the gallery musicians; as also seems to be true at the end of As You Like It, where the musicians might be conceived as being part of the duke's entourage, but hitherto his entertainment has come from individual singers, and this is more likely an occasion when, as the senior personage onstage, he simply commands the theatre's facility in this regard. Similarly, in The Winter's Tale, when Paulina stands before the statue of Hermione and commands 'Music! awake her! strike!' (5.3.98), does she bring the band on with her or, surely more likely, turn to the gallery? None of these examples proves the gallery was in use before 1608 but, coupled with recent practical experience, they make it very likely.

\section{Conclusion}

All this is not to gainsay a general development in the seventeenth century towards a more sophisticated and select indoor theatre with very probably greater specialization and a more critical self-awareness by the players of their own musical shortcomings. The question is whether the brief re-emergence of chorister theatre really brought that about at the speed and to the level currently assumed. This study does not seek to prove that instrumental/consort music in the amphitheatres was ever as extensive as it was in the early days of the revived children ca 1599-1603. Instead it simply aims to show that such music did exist in Shakespeare's plays in their outdoor performance and that the contrast between the two was not as extreme as has been portrayed. 
It seems a pity that the present Globe musicians should be conditioned to believe their work is not historically valid, just as their fellow players casting young men in their late teens and early twenties in female roles ought not to feel the need to apologize so often for the lack of that 'authentic' pre-pubescent boy. Faced with such academic disparagement, productions of Shakespeare at the Globe run the danger of becoming just the same panhistoric mélange of cultural reference and stage practice, constructed principally to satisfy the creative needs of director and designer, as anywhere else in London, and distinguished only by being housed in a tourist attraction. We should be encouraging the Globe to return to what many would regard as the original aim of the project to explore and promulgate in some detail the Elizabethan performance context (though whether they can do so without banishing those two chief anachronisms of the twentieth century is perhaps another story).

\section{Notes}

1 Harold Newcomb Hillebrand, The Child Actors (Illinois, 1926); Charles William Wallace, 'The Children of the Chapel at Blackfriars, 1597-1603', University Studies 8.2-3 (April-July 1908), 1-321.

2 William J. Lawrence, 'Music in the Elizabethan Theatre', Music Quarterly 6 (1920), 193.

3 Andrew Gurr, The Shakespearean Stage 1574-1642 (1970; rpt Cambridge, 1973), 97.

4 Andrew Gurr, The Shakespearean Stage 1574-1642 (Cambridge, 2009), 228, 182.

5 Bruce R. Smith, The Acoustic World of Early Modern England (Chicago, 1999), 220; Mary Chan, Music in the Theatre of Ben Jonson (Oxford, 1980), 33; Christopher Marsh, Music and Society in Early Modern England (Cambridge, 2010), 131.

6 Christie Carson and Farah Karim-Cooper (eds), Shakespeare's Globe: A Theatrical Experiment (Cambridge, 2008), 85, 188, 152-3.

7 Linda Austern, Music in English Children's Drama of the Later Renaissance (New York, 1992), xvii, 32-3, 51.

8 David Lindley, Shakespeare and Music (London, 2006), 98-103.

9 Andrew Gurr, The Shakespeare Company 1594-1642 (Cambridge, 2004), 81.

10 Smith, Acoustic World, 206-9.

11 John Orrell, The Human Stage: English Theatre Design, 1567-1640 (Cambridge, 1988), 61.

12 Ibid, 63. 
13 Smith, Acoustic World, 213.

14 Carson and Karim-Cooper, Shakespeare's Globe, 190.

15 Personal correspondence.

16 Carson and Karim-Cooper, Shakespeare's Globe, 187-8.

17 Austern, Music in English Children's Drama, 67-8.

18 Smith, Acoustic World, 92-3.

19 Lindley, Shakespeare and Music, 89.

20 Gurr, Shakespearean Stage (2009), 182; Lindley, Shakespeare and Music, 93.

21 Bernard Harris (ed.), The Malcontent (London, 1967), xiv.

22 'Ev.B's' dedicatory poem to the first edition in 1605 (sтc 14782). See Philip Ayres's edition of Ben Jonson, Sejanus His Fall (Manchester, 1990).

23 Lives of the English Poets, quoted in Ayres, Sejanus His Fall.

24 Austern, Music in English Children's Drama, 80.

25 Iohn Marston, The Malcontent (1604).

26 John Marston, Sophonisba (1.2 sd 40), in Peter Corbin and Douglas Sedge (eds), Three Jacobean Witchcraft Plays (Manchester, 1986). Hereafter, citations to the play will be from this edition and will appear parenthetically in the text.

27 Michael Shapiro, Children of the Revels (Columbia, 1977), 104.

28 Ian Donaldson, Oxford Poets: Ben Jonson (Oxford, 1985), 270.

29 Austern, Music in English Children's Drama, 313 n29.

30 Hillebrand, The Child Actors, 271, quoted in Austern, Music in English Children's Drama, 11. Austern notes similar views expressed by Anthony Caputi, John Marston (Cornell, 1961), 101, and Brian Gibbons, Jacobean City Comedy (London, 1980), 14.

31 Austern, Music in English Children's Drama, 11.

32 David Kathman, 'How Old Were Shakespeare's Boy Actors?', Shakespeare Survey 59 (2005), 221.

33 E.K. Chambers, The Elizabethan Stage, 4 vols (1923; rpt Oxford, 1974), 2.42.

34 Shapiro, Children of the Revels, 288.

35 Chambers, Elizabethan Stage, 2.215.

36 Ibid, 2.57.

37 'Áuthor's Note' appended John Marston, The Wonder of Women, or the Tragedie of Sophonisba (1606).

38 The King of Denmark's Welcome (1606), 16, quoted in Reavley Gair, The Children of Paul's (Cambridge, 1982), 154-5. Shen Lin, 'How Old Were the Children of Paul's?', Theatre Notebook 45 (1991), 121-31, makes an attempt to suggest the two terms are interchangeable but fails to convince, though the juniority of choristers in the Westcott period, the focus of Lin's article, is hardly a matter of contention. 
39 T. Lennam, Sebastian Westcott, the Children of Paul's and 'The Marriage of Wit and Wisdom' (Toronto, 1975), 35.

40 Shapiro, Children of the Revels, 166.

41 Austern, Music in English Children's Drama, 41; Linda Phyllis Austern, "No women are indeed": The Boy Actor as Vocal Seductress in Later Sixteenth- and Early Seventeenth- Century English Drama', in Leslie Dunn (ed.), Embodied Voices: Representing Female Vocality in Western Culture (Cambridge, 1994), 86-8.

42 G.E. Bentley, The Jacobean and Caroline Stage, 7 vols (Oxford, 1941-68), 2.433.

43 L.A. Soule, 'Subversive Rosalind: Cocky Ros in the Forest of Arden', New Theatre Quarterly 7.26 (May 1991), 126-36.

44 David Mann, Shakespeare's Women (Cambridge, 2008), 47.

45 Chambers, Elizabethan Stage, 2.51.

46 Austern, Music in English Children's Drama, 91.

47 Marsh, Music and Society, 1.

48 Baldassare Castiglione, The Book of the Courtier, trans. George Bull (London 1967), 94.

49 Thomas Elyot, The Boke Named the Governour; cited in Lindley, Shakespeare and Music, 20.

50 Edward W. Naylor, Shakespeare and Music (1896; rpt London, 1931), 4-19.

51 G. Blakemore Evans et. al. (eds), The Riverside Shakespeare (Boston, 1974). All subsequent quotations from Shakespeare's plays are taken from this edition.

52 Lindley, Shakespeare and Music, passim and 148, 150-8, 163, 175-6, 189-99, 20216, 218-33.

53 Lindley, Shakespeare and Music, 60.

54 Lawrence, 'Music in the Elizabethan Theatre', 200; Smith, Acoustic World, 220; Chan, Music in the Theatre of Ben Jonson, 32; Carson and Karim-Cooper, Shakespeare's Globe, 86, 192.

55 Lindley, Shakespeare and Music, 102.

56 Thomas Preston, Cambyses King of Percia (1584).

57 David Mann, The Elizabethan Player (London, 1991), 234-7.

58 David Bevington, From Mankind to Marlowe (Harvard, 1962), 17.

59 Lawrence, 'Music in the Elizabethan Theatre', 200.

60 Stephen Gosson, School of Abuse, 1579, in Chambers, Elizabethan Stage, 2.87. See also Marsh, Music and Society, 133.

61 Tiffany Stern, Rehearsal from Shakespeare to Sheridan (Oxford, 2000), 52-3 and passim.

62 Bentley, Jacobean and Caroline Stage, 2.691. 
63 Arlene W. Weiner, Thomas Heywood's The Iron Age (New York, 1979). Master Creak's 'noise' is mentioned in Dutch Courtesan, 2.3.120. For other Noises in plays see H. Macauley Fitzgibbon, 'Instruments and the Music in the Elizabethan Drama', Music Quarterly 17 (1931), 322.

64 Austern, Music in English Children's Drama, 70-1.

65 Gosson's Short Apology of the Schoole of Abuse, 1587, in Naylor, Shakespeare and Music, 18. Players are disparaged in Westwood Ho! 2.3, 5.3, What You Will 4.1, Mother Bombie 5.3, Epicoene 3.3, and in both parts of The Return from Parnassus, 11.360 in the first and 5.1 in the second, whilst in Shakespeare they are treated with contempt in Othello, Romeo and Juliet, and Cymbeline. See also Marsh, Music and Society, 71-106, on how 'the lousy, lowly minstrel evolved into a frequently recast figure of fun'.

66 J.B. Leishman (ed.), The Three Parnassus Plays (London, 1949), 153.

67 Robert Greene, Orlando Furioso (1594), 1.1101-2.

68 Senior Barbarisme in 1 The Return from Parnassus, 11.360, promises 'liberalitie', but Ingenioso reports he gives him 'twoo leane faces ... fiddlers wages, and dismiste me'. See the photo of a half-groat (number 2567) from 1561-77, with a lean face of Elizabeth, in Stephen Mitchell and Brian Reeds, Coins of England and the United Kingdom (London, 1989), 168. Hence, as Leishman confirms (Three Parnassus Plays, 153), their fee was a groat.

69 Chan, Music in the Theatre of Ben Jonson, 2-3.

70 R.A. Foakes, Henslowe's Diary, 2nd ed. (Cambridge, 2002), 101, 102, 122.

71 Smith, The Acoustic World, 220.

72 Lindley, Shakespeare and Music, 203.

73 Although a view currently obtains at the new Globe that these instruments were not actually played onstage (Carson and Karim-Cooper, Shakespeare's Globe, 185), Lindley (Shakespeare and Music, 101-2) argues that Henslowe's frequent purchases of musical instruments and holding of them suggest the actors played them themselves, since professional musicians would have brought their own instruments, and bought instruments would suffer if not in regular use.

74 Alan Dessen and Leslie Thomson, A Dictionary of Stage Directions in English Drama 1590-1642 (Cambridge, 1999), 146.

75 Tiffany Stern, Documents of Performance (Cambridge, 2009), 255.

76 Lawrence, 'Music in the Elizabethan Theatre', 203.

77 Gurr, Shakespearean Company, 80, 102, 106.

78 David Lindley, 'Music Authenticity and Audience', in Carson and Karim-Cooper, Shakespeare's Globe, 96, talks of 'the King's Men takeover of Blackfriars, with its larger musical resources'. 
79 Mark Eccles, 'Martin Peerson and the Blackfriars', Shakespeare Survey 11 (1958), 104, cited in Stern, Rehearsal from Shakespeare to Sheridan, 43.

80 Gurr, Shakespearean Company, 81.

81 Lawrence,'Music in the Elizabethan Theatre', 193.

82 Andrew Gurr, Shakespeare's Opposites: The Admiral's Men 1594-1625 (Cambridge, 2009), 175.

83 Marsh, Music and Society,131.

84 In both cases, the Inductions begin after the second sounding: in Cynthia's Revels the Induction is followed by the third sounding, and in The Poetaster the third sounding is followed by the Prologue.

85 Austern, Music in English Children's Drama, 81.

86 Shapiro, Children of the Revels, 254-5.

87 Austern, Music in English Children's Drama, 20, 24, 71, 73-4.

88 Chambers, Elizabethan Stage, 2.86.

89 Gurr, Shakespearean Company, $217 \mathrm{f}$ and 84.

90 Bentley, Jacobean and Caroline Stage 1.15-16.

91 Richard Fawkes, 'Realizing the Dream', Arts Management (Summer 1989), 6-11.

92 Booklet accompanying 'This World's Globe' (2 CDs), 2006, 24-5.

93 Richard Hosley, 'Was there a Music-Room in Shakespeare's Globe?', Shakespeare Survey 13 (1960), 113-23. Hosley's is a very influential article, cited by Chan, Music in the Theatre of Ben Jonson, 3-5, Lindley, Shakespeare and Music, 90ff, and R.B. Graves, Lighting the Shakespearean Stage, 1567-1642 (Carbondale, 1999), 7.

94 Andrew Gurr, Shakespearian Playing Companies (Oxford, 1996), 368.

95 Carson and Karim-Cooper, Shakespeare's Globe, 189.

96 Hosley, 'Was there a Music-Room', 118.

97 Gurr, Shakespearean Company, 78.

98 Fredson Bowers (ed.), The Complete Works of Christopher Marlowe, 2 vols (London, 1973), 2.202.

99 Marsh, Music and Society, 131; Lindley, Shakespeare and Music, 102; Smith, Acoustic World of Early Modern England, 219.

100 Celia Daileader, Eroticism on the Renaissance Stage (Cambridge, 1998), 28.

101 Carson and Karim-Cooper, Shakespeare's Globe, 82-3. 
